\title{
Influence of 2,4-D and BAP on callus growth and the subsequent regeneration of somatic embryos in long-term cultures of Pelargonium $\mathrm{x}$ domesticum cv. Madame Layal
}

\author{
Klaus-Thomas Haensch \\ Institute of Vegetable and Ornamental Crops Großbeeren/Erfurt e.V. \\ Department Plant Propagation \\ Kühnhäuser Str. 101, D-99189 Erfurt-Kühnhausen \\ Germany \\ Tel: 49036201785224 \\ Fax: 49036201785250 \\ E-mail: haensch@erfurt.igzev.de
}

Website: http://www.igzev.de

\begin{abstract}
Financial support: This investigation was undertaken with the support of the Ministries of Agriculture of the Federal Republic of Germany and the States of Brandenburg and Thüringen.
\end{abstract}

Keywords: auxin, cytokinin, pelargonium, propagation, somatic embryogenesis.

Abbreviations: $\quad 2,4$ D: 2,4 dichlorophenoxyacetic acid

BAP: 6 benzylaminopurine

This long-term study demonstrates for the first time that it is possible to propagate embryogenic cultures in pelargoniums and to subsequently initiate the differentiation of embryos using the cultivar Madame Layal (Pelargonium $x$ domesticum). Propagation of callus was only possible with combinations of 2,4dichlorophenoxyacetic acid (2,4-D) and 6benzylaminopurine (BAP), which gave rise to embryos from the primary culture stage on. However, the propagation of cells, as well as the differentiation of embryos, was inhibited by a continuous application of these growth regulators. For this reason, a long period on medium lacking growth regulators was necessary before the differentiation of embryos occurred again. The consequences for improving the propagation of embryogenic cultures in pelargoniums are discussed.

Pelargoniums are very popular ornamental plants, and their mass propagation is performed using cuttings or seeds (Mithila et al. 2001), which is very expensive. Somatic embryogenesis has the potential for establishing more efficient propagation systems.

Most published studies on somatic embryogenesis in ornamental pelargoniums are based on explants, in particular hypocotyls, of very young seedlings of Pelargonium x hortorum (Marsolais et al. 1991; Hutchinson and Saxena, 1996a; Hutchinson and Saxena, 1996b; Hutchinson et al. 1996a; Hutchinson et al. 1996b; Murthy et al. 1996; Wilson et al. 1996; Croke and Cassells, 1997; Hutchinson et al. 1997a; Hutchinson et al. 1997b;
Murthy et al. 1999; Senaratna et al. 1999; Hutchinson et al. 2000; Madakadze and Senaratna, 2000; Madakadze et al. 2000; Murch and Saxena, 2001; Senaratna et al. 2002). After a critical evaluation of these published results, and a consideration of morpho-histological studies of somatic embryo-like structures from their cultures, it was concluded that there has not yet been any proof of somatic embryogenesis from hypocotyls of this species (Haensch, 2004a). A repeated examination of this question by Madden et al. (2005) did not change this situation because once again no root pole formation could be demonstrated. However, "the most distinctive characteristic of an embryo is its anatomically discrete (closed) radicular end" (Haccius, 1978).

Other studies are based on petioles. In Pelargonium $\mathrm{x}$ hortorum, "vegetative embryos" were detected in callus formed from petioles using a medium containing zeatin and $\alpha$-naphthaleneacetic acid, and then a medium containing zeatin as the only growth regulator (Cassells, 1979). In the same species, the formation of "putative somatic embryos" in petiole cultures has been reported after applying thidiazuron (Croke and Cassells, 1997). In Pelargonium peltatum hybrids, there is a report about the regeneration of somatic embryos from petiole-derived suspension cultures using a medium with $\alpha$-naphthaleneacetic acid and thidiazuron followed by a transfer to a medium with only thidiazuron and a subsequent transfer to a medium without plant growth regulators (Robichon et al. 1997). There is another report about the regeneration of somatic embryolike structures from petioles using 6-benzylaminopurine 


\author{
Basal medium \\ with 2,4-D and BAP \\ Subculture medium \\ without 2,4-D and BAP
}

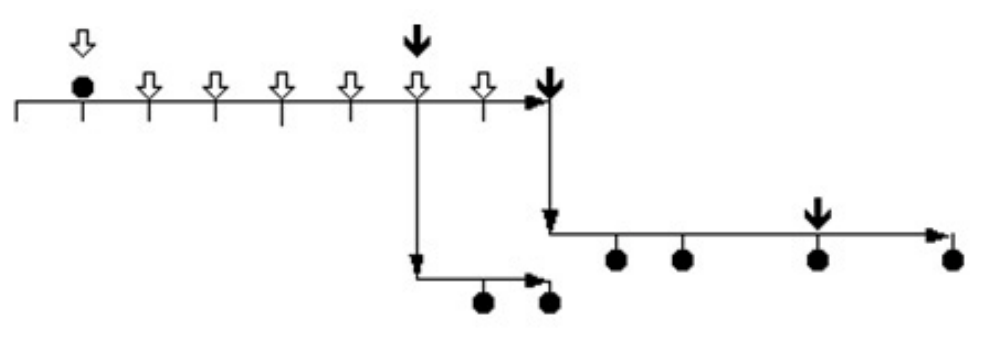

$\begin{array}{lllllllllll}0 & 4 & 8 & 12 & 16 & 20 & 24 & 28 & 32 & 36 & 40\end{array}$
58

\section{6}

Figure 1. Schedule of the experiment. BTransfer to fresh basal medium with 2,4-dichlorophenoxyacetic acid (2,4-D) and 6benzylaminopurine (BAP), WTransfer to subculture medium without growth regulators, DAssessment.

(BAP) or thidiazuron in different combinations with indole3-acetic acid or indole-3-butyric acid (Wojtania et al. 2004). In all these reports, the classification of regenerating structures as somatic embryos is unconvincing. This is because, according to the criteria formulated by Haccius (1978), the presented structures have not been shown to be clearly separated from parental explants nor have the more developed structures shown to be real bipolar structures, i.e., structures with a shoot and a root pole. The possibility of inducing somatic embryogenesis using thidiazuron in petiole cultures of Pelargonium $\mathrm{x}$ hortorum and Pelargonium $\mathrm{x}$ domesticum was histologically examined. It revealed that no somatic embryos were formed, and regenerants had to be classified as shoots and shoot- or leaflike structures (Haensch, 2004b). These findings are supported by Winkelmann et al. (2005) who also found only shoots after applying thidiazuron in petiole cultures of pelargoniums.

In other regeneration experiments with petioles of Pelargonium x hortorum and Pelargonium x domesticum, the most effective treatment for the induction of somatic embryogenesis was a medium supplemented with a combination of 2,4-dichlorophenoxyacetic acid (2,4-D) and BAP (Marsolais et al. 1991). Histological examinations of the regeneration response after the application of this method to the cultivar Madame Layal (Pelargonium $\mathrm{x}$ domesticum) confirmed that somatic embryos were formed, i.e., bipolar structures (Wilson et al. 1994). Although this protocol in combination with this cultivar was very suitable for the production of somatic embryos (Marsolais et al. 1991; Haensch, 1999), the regeneration had already occurred within four weeks after culture initiation, even on the medium with 2,4-D and BAP. For this reason, petioles are always needed for this protocol as the responding material for each regeneration process. In other species, for example Daucus carota, it is possible to propagate undifferentiated embryogenic callus on a 2,4-D-containing medium on which the development of embryos is suppressed by auxin. Afterwards, the differentiation of embryos can be initiated by transferring the callus to a medium lacking auxin (Komamine et al. 1990). Until now, there has been no procedure available in pelargoniums that allows the continuous propagation of undifferentiated embryogenic material followed by the regeneration of somatic embryos. Therefore, the objective of this study was to examine to what extent such a procedure would be possible in this species. For this purpose, we investigated the connection between different amounts of auxin and cytokinin in the medium and the resultant growth and regeneration responses.

\section{MATERIALS AND METHODS}

The experiment was performed using petioles of the cultivar Madame Layal (Pelargonium $\mathrm{x}$ domesticum). Mother plants were grown in a growth chamber at $20^{\circ} \mathrm{C}$ under a 16/8 hrs (light/dark) photoperiod with light supplied by white fluorescent lighting at an intensity of 46 $\mu \mathrm{mol} \mathrm{m} \mathrm{m}^{-1}$.

Petioles from young partially expanded leaves were surface-sterilized according to the method of Marsolais et al. (1991) by agitating them for $20 \mathrm{~min}$ in a $1.4 \%$ solution of sodium hypochlorite containing one drop of Tween 20 per $400 \mathrm{ml}$ followed by five separate rinses with sterile distilled water. The petioles were cut into $5 \mathrm{~mm}$ long segments and plated side-down, regardless of the orientation in vivo, on the surface of the culture medium. Each explant was cultivated in a $50 \mathrm{ml}$ test tube containing $10 \mathrm{ml}$ medium. The test tubes were sealed with plastic film and incubated in a growth chamber at $24^{\circ} \mathrm{C}$ under a $16 / 8 \mathrm{hrs}$ (light/dark) photoperiod with light supplied by white fluorescent lighting at an intensity of $46 \mu \mathrm{mol} \mathrm{m} \mathrm{m}^{-2} \mathrm{~s}^{-1}$. MS medium (Murashige and Skoog, 1962) with $50 \mathrm{mg} \mathrm{l}^{-1}$ ascorbic acid, $50 \mathrm{mg} \mathrm{l}^{-1}$ citric acid (Marsolais et al. 1991), $30 \mathrm{~g} \mathrm{l}^{-1}$ sucrose, and $6.5 \mathrm{~g} \mathrm{l}^{-1}$ agar at $\mathrm{pH} 5.6$ was used as the basal medium. Iron was provided as the ethylenediaminetetraacetic acid iron salt, and its content was lowered to $86.9 \mu \mathrm{mol} \mathrm{l}^{-1}$. This medium was supplemented with 2,4-D and BAP at concentrations between 0 and $18 \mu \mathrm{mol}^{-1}$ according to the experimental 
Primary culture

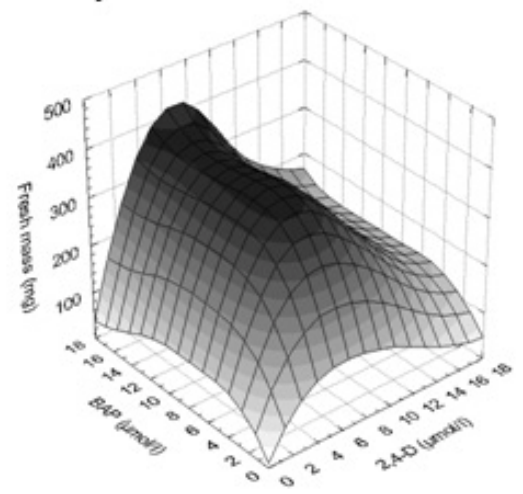

$2^{\text {nd }}$ Subculture

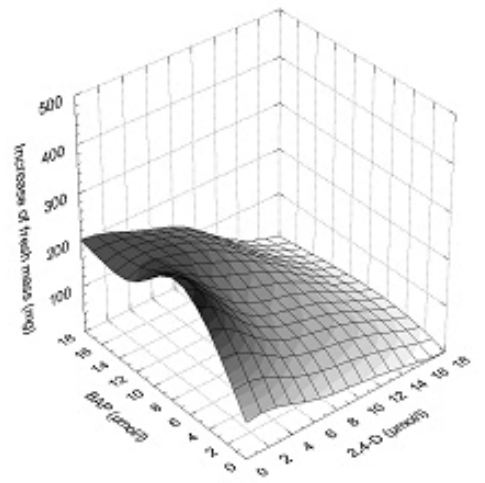

$4^{\text {th }}$ Subculture

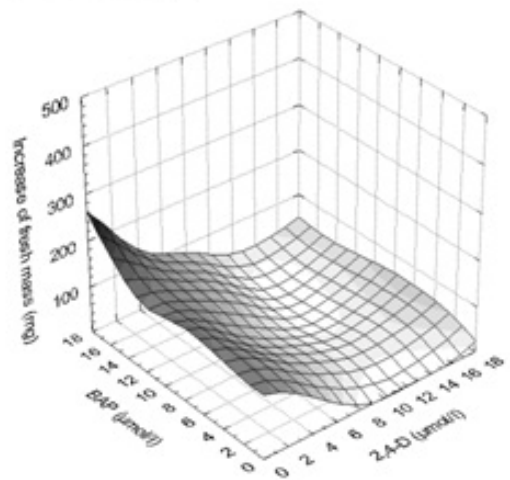

$1^{\text {st }}$ Subculture

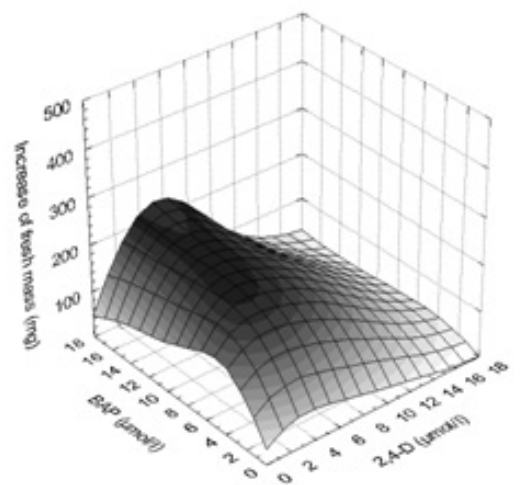

$3^{\text {rd }}$ Subculture

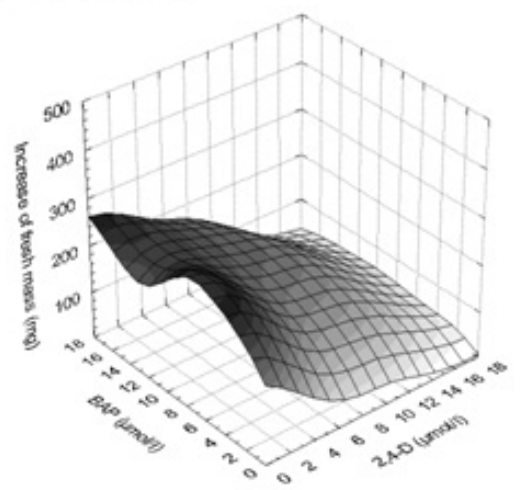

$5^{\text {th }}$ Subculture

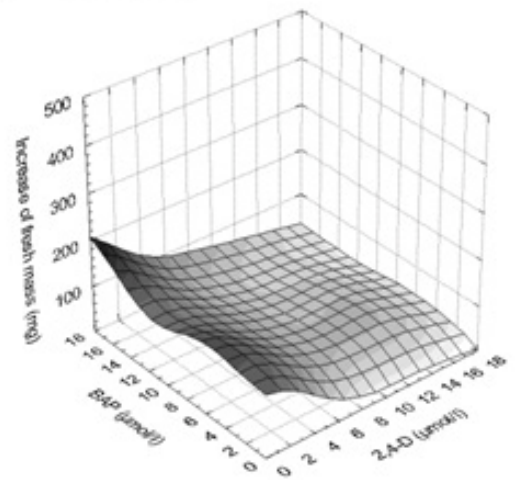

Figure 2. Fresh mass, or increases in fresh mass, of in vitro cultures from petiole segments of Pelargonium $x$ domesticum cv. Madame Layal after primary culture and following subcultures dependent on the concentration of 2,4-dichlorophenoxyacetic acid (2,4-D) and 6-benzylaminopurine (BAP) in the medium (data were smoothed using distance weighted least squares; mean initial fresh mass: $9.4 \mathrm{mg}$ ).

scheme (Figure 4). It was then autoclaved for $20 \mathrm{~min}$ at $121^{\circ} \mathrm{C}$.

Each treatment included five explants, and was not repeated. Instead of replications, the experimental scheme was extended to hundred different combinations of growth regulators to allow a comprehensive assessment of responses. The primary culture was followed by five subcultures of four weeks each on the same medium (Figure 1). After this time, half of the material in each treatment was transferred to the same medium without growth regulators for eight weeks to check the ability of the grown callus to regenerate embryos. During transfer, all embryos that had already formed were removed. The second half of the material was maintained on the former medium for a further two subcultures and then transferred to growth regulator-free medium. After 26 weeks on this medium, the material was transferred to the same medium for a further 18 weeks. For growth characterization, the fresh mass of the cultures was measured after the primary culture and after each of the first five subcultures on the growth regulator-containing medium. In addition, the initial 
value of fresh mass was determined using petiole segments from a sample of 30 explants. The kind of regeneration was determined after primary culture, four and eight weeks after transfer to the growth regulator-free medium following the fifth subculture on growth regulator-containing medium, or four, eight, and 26 weeks after transfer to the growth regulator-free medium following the seventh subculture on growth regulator-containing medium (Figure 1). A further assessment of regeneration was performed 18 weeks after the last transfer of the material to medium without 2,4-D and BAP.

The regeneration of somatic embryos on media with 2,4-D and BAP was examined histologically. For this purpose additionally cultivated petioles with globular somatic embryos were used after 10 days of the primary culture from the treatment with $10 \mu \mathrm{mol} \mathrm{l}^{-1} 2,4-\mathrm{D}$ and $2 \mu \mathrm{mol} \mathrm{l^{-1 }}$ BAP. More developed somatic embryos were obtained by cultivating petiole explants by the same methods as mentioned above with the exception that GCM medium solidified with $6 \mathrm{~g} \mathrm{l}^{-1}$ agarose and supplemented with 4.5 $\mu \mathrm{mol} \mathrm{l}^{-1} 2,4-\mathrm{D}$ and $2 \mu \mathrm{mol} \mathrm{l}^{-1}$ BAP was used followed by a transfer to the same medium without growth regulators after eight days (Marsolais et al. 1991) to increase the number of available structures. Altogether 24 explants with developing globular somatic embryos and seven more developed somatic embryos were examined. The histological examinations were performed as described by Haensch (2004a). The toluidine blue stains the cytoplasm and unlignified cell walls red and the DNA-containing structures and lignified cell walls blue.

\section{RESULTS}

\section{Growth}

The cultures produced different amounts of fresh mass dependent on the growth regulator combination and subculture (Figure 2). Based on the missing homogeneity of variances between the treatments, no analysis of variance could be performed (primary culture: Bartlett test $\chi^{2}=$ 247.4; $p<0.01$ ). For this reason, the dependence of the fresh mass, or rather the increase in fresh mass, on the auxin and cytokinin concentration was calculated using the method of distance weighted least squares.

Figure 2 shows that the region with the highest fresh mass after primary culture is with 6-8 $\mu \mathrm{mol} \mathrm{l}^{-1}$ 2,4-D in combination with 6-18 $\mu \mathrm{mol} \mathrm{l}^{-1}$ BAP. In the following five subcultures, a shift in the growth maximum towards lower 2,4-D concentrations could be observed (Figure 2). From the second subculture on, although this growth maximum seems to be mathematically below $2 \mu \mathrm{mol} \mathrm{l}^{-1} 2,4-\mathrm{D}$, real values exist only from $2 \mu \mathrm{mol} \mathrm{l}^{-1}$ upwards because many cultures without auxin had died at each step. For BAP, such a shift in the growth maximum is less clear. From the third subculture on, the highest increase in fresh mass is situated in the region between 8 and $14 \mu \mathrm{mol} \mathrm{l}^{-1}$. Considering the complete experiment, the maximal growth decreases from the primary culture to the following subcultures.

\section{Regeneration}

Most growth regulator combinations have already given rise to the formation of globular embryos during primary culture (Figure 3a and Figure 4). The histological examinations revealed that the globular stage somatic embryos are new individuals, which consist of small cells with a dense cytoplasm (Figure 3b) and develop to bipolar structures showing clearly well developed shoot and root meristems (Figure $3 \mathrm{c}$ and Figure $3 \mathrm{~d}$ ). Combinations without 2,4-D showed no somatic embryogenesis. The explants often died or remained unchanged. Some of the explants formed a small callus. The combination of $0 \mu \mathrm{mol} \mathrm{l}^{-1}$ 2,4-D with $4 \mu \mathrm{mol} \mathrm{l}^{-1}$ BAP gave rise to shoot regeneration. Combinations without BAP also showed no somatic embryogenesis, but small callus formed. All treatments with both BAP and 2,4-D gave rise to somatic embryogenesis. Exceptions were for the treatments $2 \mu \mathrm{mol}$ $1^{-1} 2,4$-D with $18 \mu \mathrm{mol} \mathrm{l}^{-1} \mathrm{BAP}$ and $16 \mu \mathrm{mol} \mathrm{l}^{-1}$ 2,4-D with 8 or $14 \mu \mathrm{mol}^{-1}$ BAP (Figure 4).

A check on the ability to regenerate somatic embryos on growth regulator-free medium after five and seven subcultures could still be performed for nearly all combinations. In treatments without auxin, this was restricted to combinations with 2,4 , and $12 \mu \mathrm{mol}^{-1}$ BAP. A check after the fifth subculture showed that there were no somatic embryos four weeks after transfer to growth regulator-free medium. Only in some combinations were a few embryos found after remaining on this growth regulator-free medium for an additional four weeks without transfer to fresh medium, i.e., only between one and three embryos on one explant each of the 2,4-D/BAP treatments $2 / 12,2 / 14,4 / 2,8 / 16,10 / 10,10 / 18$, and $14 / 4 \mu \mathrm{mol} \mathrm{l}^{-1}$.

A check after the seventh subculture on growth regulatorcontaining medium demonstrated that, after a further four and eight weeks on growth regulator-free medium, there were no somatic embryos. No somatic embryos were observed, even 26 weeks after transfer to growth regulatorfree medium. Therefore, most of this material was discarded after this stage. Only one or two calluses of the treatments $2 / 4,2 / 8,2 / 12,2 / 14,2 / 18,4 / 10,4 / 18,8 / 4,8 / 12$, and $10 / 10 \mu \mathrm{mol} \mathrm{l}^{-1} 2,4-\mathrm{D} / \mathrm{BAP}$ were transferred again to fresh growth regulator-free medium. With all of these maintained combinations on calluses that were clearly grown during this time on this medium, somatic embryos with the same appearance as in the primary culture (Figure 3a) were found after 18 weeks. Their number varied between 1 and 22 .

\section{DISCUSSION}

Until now, no procedure could be established in pelargoniums in which, after a continuous propagation of undifferentiated embryogenic material, a specific stimulus 


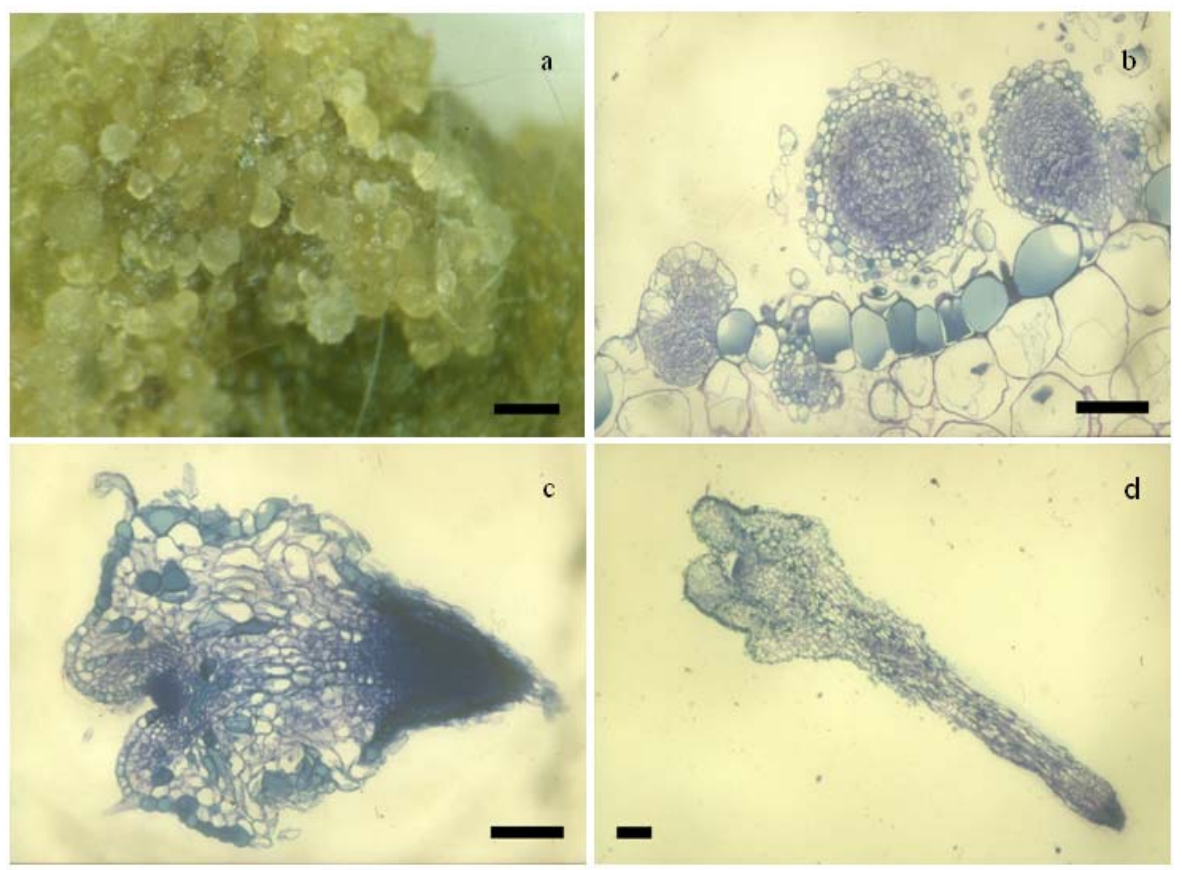

Figure 3. Somatic embryogenesis in petiole cultures of Pelargonium x domesticum cv. Madame Layal.

(a) Formation of globular stage somatic embryos on media supplemented with different concentrations of 2,4dichlorophenoxyacetic acid (2,4-D) and 6-benzylaminopurine (BAP) after primary culture as shown in Figure 4.

(b-d) Histology of the development of somatic embryos.

(b) Longitudinal section of globular stage somatic embryos formed on medium with $10 \mu \mathrm{mol} \mathrm{I}{ }^{-1}$ 2,4-D and $2 \mu \mathrm{mol} \mathrm{I} \mathrm{I}^{-1}$ BAP after 10 days in culture. The structure of the embryos is characterized by small cells with dense cytoplasm.

(c) Heart-torpedo stage embryo.

(d) Cotyledonary stage embryo.

Bar. $1 \mathrm{~mm}(\mathrm{a}) ; 0.05 \mathrm{~mm}$ (b,c); $0.1 \mathrm{~mm}$ (d).

(c-d) Longitudinal sections of more developed somatic embryos from cultures grown on medium supplemented with 4.5 $\mu$ mol $I^{-1} 2,4-D$ and $2 \mu \mathrm{mol} \mathrm{^{-1 }}$ BAP followed by a transfer to growth regulator free medium after 8 days. Note the well-organized shoot and root meristems visible as highly stained areas.

would trigger the regeneration of somatic embryos. Although there is a report about the regeneration of somatic embryos from suspension cultures in $P$. peltatum hybrids (Robichon et al. 1997), the classification of regenerating structures as somatic embryos is unconvincing because it was not shown that the one presented structure was clearly separated from the parental tissue and that the other more developed structures were real bipolar structures. The only histological report clearly confirming the formation of bipolar structures in pelargoniums is the one involving somatic embryogenesis in the cultivar Madame Layal (Pelargonium x domesticum) (Wilson et al. 1994). The results of this report are confirmed by the present study. The regenerated somatic embryos developed as new individuals that consisted in the globular stage of the typical small cells with a dense cytoplasm and developed to clear bipolar structures (Figure 3b, c and d). The regeneration of somatic embryos in this cultivar is based on the protocol of Marsolais et al. (1991), which used petioles as explants and applied a medium with 2,4-D and BAP. In this protocol, the regeneration of somatic embryos had already appeared within four weeks after culture initiation, and even on the medium with 2,4-D and BAP. Therefore, possibilities for somatic embryogenesis in pelargoniums are restricted at present to the production of embryos on primary explants. In other species, for example D. carota, undifferentiated embryogenic callus can be established and propagated on a 2,4-D-containing medium, whereas a subsequent transfer to a medium lacking auxin initiates the differentiation of embryos (Komamine et al. 1990). Therefore, the objective of this study was to examine to what extent such a method would be realizable in pelargoniums. For this purpose, we investigated the connection between different concentrations of 2,4-D and BAP in the medium and the resultant growth and regeneration responses of petiole cultures of the cultivar Madame Layal (Pelargonium $\mathrm{x}$ domesticum) in a long-term experiment. 
The results represent a comprehensive survey of these responses, which were obtained with a small sample size and without a replication, but with a high number of growth regulator combinations. This special statistical approach is suitable to get such a survey (Baetz et al. 1982) but prevents to make differences between single treatments statistically evident. This has to be considered when such special differences will be assessed.

Concerning the growth of the cultures, it became apparent that growth at a combination of $10 \mu \mathrm{mol} \mathrm{l}^{-1} 2,4-\mathrm{D}$ with 2 $\mu \mathrm{mol} \mathrm{l}^{-1} \mathrm{BAP}$, which Marsolais et al. (1991) found to be the optimum concentration for the regeneration of somatic embryos in cv. Madame Layal, was much lower than the maximum values at all culture stages (Figure 2). Furthermore, the maximum of fresh mass increase shifted with subsequent subcultures from 6-8 $\mu \mathrm{mol} \mathrm{l}^{-1} 2,4-\mathrm{D}$ in combination with 6-18 $\mu \mathrm{mol} \mathrm{l}^{-1}$ BAP to very low 2,4-D concentrations in combination with almost unchanged BAP concentrations. An explanation for the considerably lower growth at higher auxin concentrations with increasing culture time could be growth inhibition caused by the enrichment of 2,4-D in the tissues, as was shown in Arabidopsis (Meijer et al. 1999). The regeneration observed during primary culture shows that, with this cultivar, the formation of globular embryos already occurs in a broad spectrum of 2,4-D/BAP combinations four weeks after culture initiation on these media. On the one hand, these embryos are produced even in situations in which the concentrations are suboptimal or already clearly inhibiting growth (Figure 2, primary culture, and Figure 4). On the other hand, in growth regulator combinations without the regeneration of embryos, the callus growth is so small that it is unsuitable for propagation. For this reason, propagation is only possible with combinations that trigger the regeneration of embryos already in the primary culture. However, our results show that, after five and seven subcultures on these media, embryogenic responses are rarely or no longer detectable if the cultures are transferred to growth regulator-free medium.

Several explanations for this effect are possible. One possibility is that the medium without growth regulators might be unsuitable for the development of embryos. However, Marsolais et al. (1991) showed that the used cultivar regenerates embryos after a 2,4-D application of only 2-8 days followed by a transfer to growth regulatorfree medium. Therefore, this explanation can be excluded. Another possibility is the embryos originate from already embryogenic determined cells. Such embryogenesis can lead directly to globular embryos through which the stock of embryogenic cells would be exhausted after a certain time. In the histological analysis of Wilson et al. (1994), no pre-embryogenic determined cells were reported. The analysis shows that normal sub epidermal parenchyma cells are the origin of embryogenesis. These cells are stimulated to embryogenesis by the application of 2,4-D in combination with BAP. For this reason, the greatly diminished embryogenic response in a growth regulatorfree subculture following a longer application of 2,4-D and BAP cannot be explained by the exhaustion of a stock of embryogenic determined cells. It has to be interpreted as an inhibition effect of the long-lasting influence of the growth regulators used. This explanation is also supported by the fact that, in the case of very long subculture on growth regulator-free medium, some embryos are again formed on newly formed callus. The same processes as were discussed with regard to the inhibition of growth supposedly cause this inhibition.

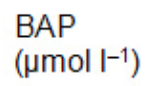

\begin{tabular}{|c|c|c|c|c|c|c|c|c|c|c|}
\hline 18 & - & $\square$ & $\times$ & $\times$ & $\times$ & $\times$ & $\times$ & $\times$ & $\times$ & $\times$ \\
\hline 16 & - & $\times$ & $\times$ & $\times$ & $\times$ & $\times$ & $\times$ & $\times$ & $\times$ & $\times$ \\
\hline 14 & - & $\times$ & $\times$ & $\times$ & $\times$ & $\times$ & $\times$ & $\times$ & $\square$ & $\times$ \\
\hline 12 & $\square$ & $\times$ & $\times$ & $\times$ & $\times$ & $\times$ & $\times$ & $\times$ & $\times$ & $\times$ \\
\hline 10 & $\bullet$ & $\times$ & $\times$ & $\times$ & $\times$ & $\times$ & $\times$ & $\times$ & $\times$ & $\times$ \\
\hline 8 & - & $\times$ & $\times$ & $\times$ & $\times$ & $\times$ & $\times$ & $\times$ & $\square$ & $\times$ \\
\hline 6 & - & $\times$ & $\times$ & $\times$ & $\times$ & $\times$ & $\times$ & $\times$ & $\times$ & $\times$ \\
\hline 4 & $\triangle$ & $\times$ & $\times$ & $\times$ & $\times$ & $\times$ & $\times$ & $\times$ & $\times$ & $\times$ \\
\hline 2 & $\square$ & $\times$ & $\times$ & $\times$ & $\times$ & $\times$ & $\times$ & $\times$ & $\times$ & $\times$ \\
\hline 0 & - & $\square$ & $\square$ & $\square$ & $\square$ & $\square$ & $\square$ & $\square$ & $\square$ & $\square$ \\
\hline
\end{tabular}

$2,4-\mathrm{D}(\mu \mathrm{mol} \mathrm{I-1})$

Figure 4. Regeneration on petiole segments of Pelargonium x domesticum cv. Madame Layal cultivated in vitro dependent on the concentration of 2,4-dichlorophenoxyacetic acid (2,4-D) and 6-benzylaminopurine (BAP) after primary culture. n no response, $\square$ only callus formation, $x$ embryos, $\Delta$ shoot formation. 
These results demonstrate for the first time that it is possible to propagate embryogenic cultures in pelargoniums, and to subsequently initiate the differentiation of embryos using the cultivar Madame Layal (Pelargonium $\mathrm{x}$ domesticum). However, the propagation of cells, as well as the differentiation of embryos, was inhibited for a long time by a continuous propagation on media containing 2,4-D and BAP. This knowledge could contribute to improving the propagation of embryogenic cultures and the subsequent regeneration of embryos in Pelargonium $\mathrm{x}$ domesticum. It could even be applied to the economically important Pelargonium $\mathrm{x}$ hortorum and $P$. peltatum hybrids, because using the protocol in these species gave rise to somatic embryos, but with only very low regeneration rates (Marsolais et al. 1991; Haensch, 1999).

One approach for such improvements might be, for example, the elimination of growth regulators after a certain time by binding them to active charcoal or washing them away by frequently changing the medium. This has proven successful in overcoming the inhibition of somatic embryogenesis caused by accumulated 2,4-D in Arabidopsis cell suspensions (Meijer et al. 1999). Other approaches might be the repeated switching between development and disorganization of somatic embryos, as was found suitable for maintaining embryogenic competence in carrots (Nomura, 2003), or the substitution of growth regulators during the induction of somatic embryogenesis by alternative means such as salt stress, as was also possible in ginseng (Choi et al. 1998).

\section{ACKNOWLEDGMENTS}

The author would like to thank Mrs Barbara Weinlich for her excellent technical assistance. The author also wishes to acknowledge the company Fischer $\mathrm{GmbH} \& \mathrm{Co} \mathrm{KG}$ Hillscheid, Germany, for the supply of the cultivar.

\section{REFERENCES}

BAETZ, Gerd; DOERFEL, Hannelore; FUCHS, Armin and THOMAS, Erhard. Einführung in die Methodik des Feldversuchs. Berlin, VEB Deutscher Landwirtschaftsverlag, 1982. 327 p. ISBN 3-33-100125-2.

CASSELLS, Alan C. The effect of 2,3.5 Triiodbenzoic acid on caulogenesis in callus cultures of Tomato and Pelargonium. Physiologia Plantarum, June 1979, vol. 46, no. 2, p. 159-164.

CHOI, Yong-Eui; YANG, Deok-Chun and CHOI, KwangTae. Induction of somatic embryos by macrosalt stress from mature zygotic embryos of Panax ginseng. Plant Cell, Tissue and Organ Culture, March 1998, vol. 52, no. 3, p. 177-181.

CROKE, Joseph T. and CASSELLS, Alan C. Dark induction and genetic stability of somatic embryos of zonal geraniums (Pelargonium x hortorum Bailey). Journal of
Applied Botany, November 1997, vol. 71, no. 3-4, p. 119124.

HACCIUS, Barbara. Question of unicellular origin of nonzygotic embryos in callus cultures. Phytomorphology, March 1978, vol. 28, no. 1, p. 74-81.

HAENSCH, Klaus-Thomas. Somatic embryogenesis in vitro from adult plants of Pelargonium: influence of genotype and basal medium. Gartenbauwissenschaft, September-October 1999, vol. 64, no. 5, p. 193-200.

HAENSCH, Klaus-Thomas. Morpho-histological study of somatic embryo-like structures in hypocotyl cultures of Pelargonium x hortorum Bailey. Plant Cell Reports, January 2004a, vol. 22, no. 6, p. 376-381.

HAENSCH, Klaus-Thomas. Thidiazuron-induced morphogenetic response in petiole cultures of Pelargonium $\mathrm{x}$ hortorum and Pelargonium $\mathrm{x}$ domesticum and its histological analysis. Plant Cell Reports, October 2004b, vol. 23, no. 4, p. 211-217.

HUTCHINSON, Margaret J. and SAXENA, Praveen K. Acetylsalicylic acid enhances and synchronizes thidiazuron-induced somatic embryogenesis in geranium (Pelargonium $\mathrm{x}$ hortorum Bailey) tissue cultures. Plant Cell Reports, March 1996a, vol. 15, no. 7, p. 512-515.

HUTCHINSON, Margaret J. and SAXENA, Praveen K. Role of purine metabolism in thidiazuron-induced somatic embryogenesis of geranium (Pelargonium x hortorum) hypocotyl cultures. Physiologia Plantarum, November 1996b, vol. 98 , no. 3, p. 517-522.

HUTCHINSON, Margaret J.; KRISHNARAJ, Sankaran and SAXENA, Praveen K. Morphological and physiological changes during thidiazuron-induced somatic embryogenesis in geranium (Pelargonium $\mathrm{x}$ hortorum Bailey) hypocotyl cultures. International Journal of Plant Sciences, July 1996a, vol. 157, no. 4, p. 440-446.

HUTCHINSON, Margaret J.; MURCH, Susan J. and SAXENA, Praveen K. Morphoregulatory role of thidiazuron: evidence of the involvement of endogenous auxin in thidiazuron-induced somatic embryogenesis of geranium (Pelargonium x hortorum Bailey). Journal of Plant Physiology, October 1996b, vol. 149, no. 5, p. 573579.

HUTCHINSON, Margaret J.; KRISHNARAJ, Sankaran and SAXENA, Praveen K. Inhibitory effect of $\mathrm{GA}_{3}$ on the development of thidiazuron-induced somatic embryogenesis in geranium (Pelargonium $\mathrm{x}$ hortorum Bailey) hypocotyl cultures. Plant Cell Reports, March 1997a, vol. 16 , no. 6 , p. 435-438.

HUTCHINSON, M.J.; MURR, D.; KRISHNARAJ, S.; SENARATNA, T. and SAXENA, P.K. Does ethylene play a role in thidiazuron-regulated somatic embryogenesis of 
geranium (Pelargonium x hortorum Bailey) hypocotyl cultures? In Vitro Cellular and Developmental Biology Plant, April 1997b, vol. 33, no. 2, p. 136-141.

HUTCHINSON, M.J.; SENARATNA, T.; SAHI, S.V. and SAXENA, P.K. Light mediates endogenous plant growth substances in thidiazuron-induced somatic embryogenesis in geranium hypocotyl cultures. Journal of Plant Biochemistry and Biotechnology, January 2000, vol. 9, no. 1, p. 1-6.

KOMAMINE, Atsushi; MATSUMOTO, Masami; TSUKAHARA, Masayoshi; FUJIWARA, Arihito; KAWAHARA, Ryoichi; ITO, Masaki; SMITH, Jane; NOMURA, Koji and FUJIMURA, Tatsuhito. Mechanisms of somatic embryogenesis in cell cultures - physiology, biochemistry and molecular biology. In: NIJKAMP, H.J.J.; VAN DER PLAS, L.H.W. and VAN AARTRIJK, J. eds. Progress in plant cellular and molecular biology. Dordrecht, Kluwer Academic Publishers, 1990, p. 307-313.

MADAKADZE, R.M. and SENARATNA, T. Effect of growth regulators on maturation of geranium (Pelargonium $\mathrm{x}$ hortorum) somatic embryos. Plant Growth Regulation, January 2000, vol. 30, no. 1, p. 55-60.

MADAKADZE, R.M.; KROCHKO, J.E. and SENARATNA, T. Identification and characterization of storage proteins in zygotic and somatic embryos of geranium (Pelargonium $\mathrm{x}$ hortorum). Journal of the American Society for Horticultural Science, July 2000, vol. 125 , no. 4 , p. 525-529.

MADDEN, Jaren I.; JONES, Cynthia S. and AUER, Carol A. Modes of regeneration in Pelargonium $\mathrm{x}$ hortorum (Geraniaceae) and three closely related species. In Vitro Cellular and Developmental Biology - Plant, JanuaryFebruary 2005, vol. 41, no. 1, p. 37-46.

MARSOLAIS, A.A.; WILSON, D.P.M.; TSUJITA, M.J. and SENARATNA, T. Somatic embryogenesis and artificial seed production in zonal (Pelargonium $\mathrm{x}$ hortorum) and regal (Pelargonium $\mathrm{x}$ domesticum) geranium. Canadian Journal of Botany, June 1991, vol. 69, no. 6, p. 1188-1193.

MEIJER, E.A.; DE VRIES, S.C. and MORDHORST, A.P. Co-culture with Daucus carota somatic embryos reveals high 2,4-D uptake and release rates of Arabidopsis thaliana cultured cells. Plant Cell Reports, March 1999, vol. 18, no. 7-8, p. 656-663.

MITHILA, Jugulam; MURCH, Susan J.; KRISHNARAJ, Sankaran and SAXENA, Praveen K. Recent advances in Pelargonium in vitro regeneration systems. Plant Cell, Tissue and Organ Culture, October 2001, vol. 67, no. 1, p. $1-9$.

MURASHIGE, Toshio and SKOOG, Folke. A revised medium for rapid growth and bioassays with tobacco tissue cultures. Physiologia Plantarum, July 1962, vol. 15, no. 3, p. $473-497$.

MURCH, Susan J. and SAXENA, P.K. Molecular fate of thidiazuron and its effects on auxin transport in hypocotyls tissues of Pelargonium x hortorum Bailey. Plant Growth Regulation, November 2001, vol. 35, no. 3, p. 269-275.

MURTHY, B.N.S.; SINGH, R.P. and SAXENA, P.K. Induction of high-frequency somatic embryogenesis in geranium (Pelargonium x hortorum Bailey cv. Ringo Rose) cotyledonary cultures. Plant Cell Reports, February 1996, vol. 15 , no. 6, p. 423-426.

MURTHY, B.N.S.; VETTAKKORUMAKANKAV, N.N.; KRISHNARAJ, S.; ODUMERU, J. and SAXENA, P.K. Characterization of somatic embryogenesis in Pelargonium $\mathrm{x}$ hortorum mediated by a bacterium. Plant Cell Reports, March 1999, vol. 18, no. 7-8, p. 607-613.

NOMURA, K. Long-term conservation of embryogenic competence by induction and disorganization of somatic embryos in carrot. Plant Breeding, August 2003, vol. 122, no. 4, p. 343-346.

ROBICHON, M-P.; RENOU, J-P. and JALOUZOT, R. Plant regeneration of ivy leaved geranium through shoot organogenesis. Plant Cell, Tissue and Organ Culture, June 1997, vol. 49, no. 3, p. 209-212.

SENARATNA, Tissa; DIXON, Kingsley; BUNN, Eric and TOUCHELL, Darren. Smoke-saturated water promotes somatic embryogenesis in geranium. Plant Growth Regulation, June 1999, vol. 28, no. 2, p. 95-99.

SENARATNA, Tissa; BUNN, Eric and BISHOP, Anthony. Triazole treatment of explant source provides stress tolerance in progeny of geranium (Pelargonium hortorum Bailey) plants regenerated by somatic embryogenesis. Plant Growth Regulation, February 2002, vol. 36, no. 2, p. 169174.

WILSON, D.P.M.; SULLIVAN, J.A.; MARSOLAIS, A.A. and TSUJITA, M.J. Histology of somatic embryogenesis in regal geranium. Journal of the American Society for Horticultural Science, May 1994, vol. 119, no. 3, p. 648651.

WILSON, D.P.M.; SULLIVAN, J.A.; MARSOLAIS, A.A.; TSUJITA, M.J. and SENARATNA, T. Improvement of somatic embryogenesis in zonal geranium. Plant Cell, Tissue and Organ Culture, February 1996, vol. 47, no. 1, p. 27-32.

WINKELMANN, Traud; KAVIANI, Kamran and SEREK, Margrethe. Development of a shoot regeneration protocol for genetic transformation in Pelargonium zonale and Pelargonium peltatum hybrids. Plant Cell, Tissue and Organ Culture, January 2005, vol. 80, no. 1, p. 33-42. 
WOJTANIA, Agnieszka; GABRYSZEWSKA, Eleonora and MARASEK, Agnieszka. Regeneration of Pelargonium $\mathrm{x}$ hederaefolium 'Bonete' from petiole explants. Acta Physiologiae Plantarum, 2004, vol. 26, no. 3, p. 255-262. 